\title{
“Tibupoeg Pio" maagia ehk väärtusliku traditsioonilise teksti ootamatust esiletõusust ${ }^{1}$
}

\begin{abstract}
Maria Zavjalova
Teesid: Artikkel keskendub Itaalias 2012. aastal tõeliseks hitiks kujunenud laulukesele "Il Pulcino Pio" ("Tibupoeg Pio") ja analüüsib selle populaarsuse põhjusi. Lähemal uurimisel kerkib pinnale pealtnäha lihtsakoelise ja erilise sisuta laulukese sügav semiootilisus ja saab selgeks selle pärinemine teadvuse vanimatest kihtidest. Analüüsi käigus tuuakse välja peamised tegurid, mis aitasid laulul end masside teadvusse kinnistuda: kumulatiivseid muinasjutte, liisusalme ja primitiivseid laulukesi meenutav lastelaulu vorm; teksti ja videojada ahelstruktuur; loomade hääljäljendused ja kergesti meeldejääv rütm; ootamatu finaal; elukäiku kopeerivate arhetüüpsete ettekujutuste kompleks, mis on seotud tibupoja munast välja tuleku ja muna sümboolikaga.
\end{abstract}

Märksõnad: folkloor, hitid, liisusalmid, massikultuur, "Tibupoeg Pio"

Tundub, et mitte miski pole arhailisest folklooritekstist nii kaugel kui tänapäeva massikultuur. Meie hullumeelsete rütmide ja sootuks teistsuguse esteetika ajastul on raske ette kujutada rituaalsete tantsude või rahvapäraste tšastuškade üleüldist harrastamist. Siiski kerkib mõningate tänapäeva massikultuuri nähtuste lähemal analüüsimisel pinnale nende sügav semiootilisus ja arhetüübi pärinemine kaugest minevikust. Ühest sellisest nähtusest tuleb juttu käesolevas artiklis. Jättes kõrvale arutlused popphitist kui sellisest (ja hittide vastuvõtumehhanismidest üldse) vaatleme selle üksiknäidet - nimelt Itaalia 2012. aasta hitti "Il Pulcino Pio".

Itaalias on kasutusel termin tormentone estivo. Sellega tähistatakse populaarset muusikahitti (see on üldjuhul kerge ja rütmikas, mille järgi saab rannas tantsida), mis pealetükkivalt kõlab kogu suve raadiojaamades ja klubides. Pärast hooaja lõppu laulu populaarsus tavaliselt kahaneb, selle asemele tuleb uus, ja nii kordub igal aastal. Ent 2012. aastal juhtus midagi enam kui tavatut: populaarses raadiojaamas Radio Globo hooaja alguses (mais) üllitatud lauluke "Il Pulcino Pio" tõusis väga kiiresti (mõne nädalaga) edetabeli tippu, 
püsis tipus kogu suve ja isegi kuus kuud pärast hooaja lõppu selle populaarsus aina suurenes. Hitt teenis välja kuld- ja plaatinaplaadi, viimaks - kui oli läbi müüdud üle 60000 koopia - koguni kahekordse plaatinaplaadi.

Analüütikud räägivad sellega seoses niisuguste muusikapalade ajaloo suurimast edust, massipsühhoosist, mis oli haaranud kogu Itaalia. Nad nimetasid hitti seejuures jampslikuks lastelauluks, painavaks ja tüütuks liisusalmiks. Tegelikult, vaadates rannal puhkavaid rahvahulki selle laulukese rütmis lustimas $^{3}$ (ja seda kogu suve terves Itaalias), võib mõelda omamoodi hullusest või poolsaart tabanud nakkushaigusest (nakkushaiguseks või DNA viiruseks nimetavad seda laulukest ka Itaalia kriitikud). Selle hitiga seotud hullus ei ole üksnes metafoorne, vaid reaalne: fikseeritud on juhtumeid, kus on pekstud seda laulukest laulnud inimesi, kes ei suutnud seda tõelisse ekstaasi sattununa järele jätta (Capocelli 2012). Loomulikult ei saa selline hullumeelne meelelahutus jääda vastureaktsioonita: Itaalias ütlevad paljud, et vihkavad seda laulu, internetis loodi kogukondi, kes ihkasid “tappa tibu Piot”, mis loomulikult suurendas laulu populaarsust.

See fenomen ei saanud jätta külmaks eksperte: "tibupoeg Pio juhtumit" uurivad sotsioloogid, turundusasjatundjad, etnograafid, psühholoogid ja isegi psühhiaatrid, seda käsitlesid telesaated, artiklid ajakirjanduses ja blogid. Digitaalse etnograafia uurimise keskus (Centro Studi Etnografia Digitale) avaldas statistika, mille kohaselt on välja antud üle 1000 video, mis sisaldavad märksõnu pulcino pio, iga videoga seotud kommentaaride hulk oli selleks hetkeks 24384 (Caliandro \& Beraldo 2012). Üksnes ametlikku versiooni oli Youtube'is vaadatud üle 60 miljoni korra, mida on Itaalia kohta uskumatult palju. Lisaks ametlikule versioonile leidub tohutu hulk variatsioone, töötlusi, paroodiaid, instseneeringuid, tantsusalvestisi jne. Alates sügisest (see tähendab juba pärast hooaja lõppu, mis on tavaliselt selliste laulude populaarsuse tipphetk) hakkasid ilmuma selle klipi variandid teistes keeltes (alguses prantsuse ja kreeka, seejärel inglise, portugali ja hispaania keeles), 2013. aasta suveks oli internetis klipist eri keeltes kümme versiooni, üks isegi mitmes keeles, sellesse on koondatud kõik versioonid. ${ }^{4}$

Mis on põhjustanud selle fenomeni, mida võib mõnes mõttes nimetada tänapäeva massikultuuri sündmuseks?

\section{Laulu struktuurist ja žanrist}

Vaatame kõigepealt uurimisobjekti. "Il Pulcino Pio" (singli ametlik versioon http://www.youtube.com/watch?v=juqyzgnbspY) on laste liisusalmi meenutav lihtsakoeline rütmiline lauluke, mis tundub esimesel pilgul mõttetu. Videoklipp 
kujutab endast vahelduvaid joonistatud loomi (need on peaaegu staatilised, noogutavad ainult rütmiliselt pead või liigutavad jalgu või käppi), kes toovad kuuldavale neile iseloomulikke häälitsusi, saateks nende helide nimetused häälte omamoodi akustiline vormel, mis on traditsioonis omaks võetud.

Videojada algab munast väljavupsava tibuga, talle järgnevad hierarhilises korras suuremad olevused (kanast härjani), uue tegelase ilmumisele järgneb tagasiulatuv aruanne, mis kordab kõiki eelmisi tegelasi ja lõpeb tibuga. Video lõpeb ootamatult: ilmub traktor, mis lömastab tibu.

\section{Il Pulcino Pio}

In radio c'è un pulcino, in radio c'è un pulcino...

e il pulcino pio, e il pulcino pio, e il pulcino pio, e il pulcino pio, e il pulcino pio, e il pulcino pio...

In radio c'è una gallina, in radio c'è una gallina...

e la gallina cò, e il pulcino pio

e il pulcino pio, e il pulcino pio,

e il pulcino pio, e il pulcino pio...

In radio c'è anche un gallo, in radio c'è anche un gallo...

e il gallo corococò e la gallina cò e il pulcino pio, e il pulcino pio, e il pulcino pio, e il pulcino pio...

In radio c'è un tacchino, in radio c'è un tacchino...

e il tacchino glu glu glu, il gallo corococò e la gallina cò e il pulcino pio, e il pulcino pio, e il pulcino pio...

In radio c'è un piccione, in radio c'è un piccione...

e il piccione tru e il tacchino glu glu glu

e il gallo corococò e la gallina cò

e il pulcino pio, e il pulcino pio,

e il pulcino pio, e il pulcino pio...

In radio c'è anche un gatto, in radio c'è anche un gatto...

e il gatto miao, il piccione tru

e il tacchino glu glu glu e il gallo corococò

e la gallina cò e il pulcino pio

e il pulcino pio, e il pulcino pio...

\section{Tibupoeg Pio}

Raadios on tibupoeg, raadios on tibupoeg...

tibupoeg pio, tibupoeg pio, tibupoeg pio, tibupoeg pio, tibupoeg pio, tibupoeg pio...

Raadios on kana, raadios on kana...

Kana ka-ka-kaa ja tibupoeg pio, ja tibupoeg pio, tibupoeg pio, ja tibupoeg pio, tibupoeg pio...

Raadios on ka kukk, raadios on ka kukk...

Kukk kikerikii ja kana ka-ka-kaa ja tibupoeg pio, tibupoeg pio, ja tibupoeg pio, tibupoeg pio...

Raadios on kalkun, raadios on kalkun...

Kalkun kul-kul-kul ja kukk kikerikii ja kana ka-ka-kaa ja tibupoeg pio ja tibupoeg pio, tibupoeg pio...

Raadios on tuvi, raadios on tuvi...

Tuvi kulu-kulu ja kalkun kul-kul-kul ja kukk kikerikii ja kana ka-ka-kaa ja tibupoeg pio, tibupoeg pio, ja tibupoeg pio, tibupoeg pio...

Raadios on kass, raadios on kass...

Kass näu-näu, tuvi kulu-kulu ja kalkun kul-kul-kul ja kukk kikerikii ja kana ka-ka-kaa ja tibupoeg pio ja tibupoeg pio, tibupoeg pio... 
In radio c'è anche un cane, in radio c'è anche un cane...

e il cane bau bau, il gatto miao, e il piccione tru e il tacchino glu glu glu e il gallo corococò e la gallina cò e il pulcino pio, e il pulcino pio, e il pulcino pio, e il pulcino pio...

In radio c'è una capra, in radio c'è una capra...

e la capra meee e il cane bau bau, e il gatto miao, e il piccione tru e il tacchino gulu gulu e il gallo corococò e la gallina cò e il pulcino pio e il pulcino pio, e il pulcino pio...

In radio c'è un agnello, in radio c'è un agnello...

e l'agnello bee e la capra meee

e il cane bau bau, il gatto miao, e il piccione tru e il tacchino gulu gulu e il gallo corococò e la gallina cò e il pulcino pio, e il pulcino pio, e il pulcino pio, e il pulcino pio...

In radio c'è una mucca, in radio c'è una mucca...

e la mucca moo, l'agnello bee e la capra meee e il cane bau bau, il gatto miao, e il piccione tru e il tacchino glu glu glu e il gallo corococò e la gallina cò e il pulcino pio e il pulcino pio, e il pulcino pio, e il pulcino pio, e il pulcino pio...

In radio c'è anche un toro, in radio c'è anche un toro...

e il toro muu e la mucca moo l'agnello bee e la capra meee e il cane bau bau, il gatto miao, e il piccione tru e il tacchino glu glu glu e il gallo corococò e la gallina cò e il pulcino pio, e il pulcino pio, e il pulcino pio, e il pulcino pio...

In radio c'è un trattore, in radio c'è un trattore

e il trattore bruum, il trattore bruum, il trattore bruum e il pulcino.....(squeck) .....oh oh.....
Raadios on koer, raadios on koer...

Koer auh-auh, kass näu-näu, tuvi kulu-kulu, kalkun kul-kul-kul, kukk kikerikii, kana ka-ka-kaa ja tibupoeg pio, tibupoeg pio, ja tibupoeg pio, tibupoeg pio...

Raadios on kits, raadios on kits...

Kits köki-möki ja koer auh-auh, kass näu-näu, tuvi kulu-kulu, kalkun kul-kul-kul, kukk kikerikii, kana ka-ka-kaa ja tibupoeg pio ja tibupoeg pio, tibupoeg pio...

Raadios on talleke, raadios on talleke...

talleke mää, kits köki-möki, koer auh-auh, kass näu-näu, tuvi kulu-kulu, kalkun kul-kul-kul, kukk kikerikii, kana ka-ka-kaa ja tibupoeg pio, tibupoeg pio, ja tibupoeg pio, tibupoeg pio...

Raadios on lehm, raadios on lehm...

Lehm ammuu, talleke mää, kits köki-möki, koer auh-auh, kass näu-näu, tuvi kulu-kulu, kalkun kul-kul-kul, kukk kikerikii, kana ka-ka-kaa ja tibupoeg pio, ja tibupoeg pio, tibupoeg pio, ja tibupoeg pio, tibupoeg pio...

Raadios on härg, raadios on härg...

Härg möö, lehm ammuu, talleke mää, kits köki-möki, koer auh-auh, kass näu-näu, tuvi kulu-kulu, kalkun kul-kul-kul, kukk kikerikii, kana ka-ka-kaa ja tibupoeg pio, tibupoeg pio, ja tibupoeg pio, tibupoeg pio...

Raadios on traktor, raadios on traktor, traktor põrr, traktor põrr, traktor põrrpõrr, ja tibupoeg... (kriiks)... oi-oi... 
Oma päritolu võlgneb see klipp Brasiilia samanimelisele laulule "O Pintinho", mille lõi 1985. aastal helilooja Erisvaldo da Silva. Aasta enne Itaalia versiooni ilmus Brasiilia klipp, kuid see ei kutsunud esile mingeid kirgi. ${ }^{5}$ Tõsi, Brasiilia variandis puudub tragikoomiline finaal (traktor) ja videojada ei ole nii ere kui itaalia klipis. Kuid kas sellise uskumatu populaarsuse taga on üksnes ootamatu finaal või peitub põhjus milleski muus?

Kõigepealt pöördume selle hiti žanri juurde. Pole sugugi ilmaasjata, et peaaegu kõik kutsuvad seda laulukest filastrocca, mis tähendab lastelaulukest, liisusalmi. Assotsiatsioonid liisusalmiga tekivad loendamist meenutava loetelu tõttu, mis tundub olevat täiesti mõttetu. Tõepoolest on liisusalmide silmapaistvaks eripäraks nende absurdsus, orienteeritus mitte loogikale, vaid helile ja rütmile. Larissa Melnikova iseloomustab liisusalme järgmiselt: "Liisusalmide kõige üldisemad eripärad on: lühidus, täpne rütm, riimi kasutamine, kõlavus, rikkalik instrumentatsioon, süntaktiline lihtsus, "arusaamatute" elementide olemasolu, leksika primitiivsus, sageli esinev alogism” (Melnikova 1990: 113). Kõlab sarnaselt, välja arvatud võib-olla vaid "arusaamatud elemendid", mida kirjeldatud tekstis ei ole. Selles puudub sisu peaaegu üldse, mida ei saa öelda liisusalmide kohta. Nendes on üldjuhul olemas tegelased ja tegevus, kuigi see tegevus võib olla täiesti absurdne (näiteks "Sõitis papp sea seljas, balalaika seljas..." või "Istub härra tamme otsas, surub looka toomingat" (tsiteeritud Melnikova 1990: 119-120)).

Alogoism, absurdsus ja tekstis tähelepanukeskme nihutamine mõttelt rütmile lähendab liisusalme teisele folkloorižanrile - loitsudele (neid peetakse lähedasteks liisusalmidele, mida mitmed teadlased seostavad iidsete maagiliste rituaalidega (vt nt Metškovskaja 1998: 105). Meenutame näiteks kõige tuntumat abrakadabra tüüpi kabalistlikku loitsu, mis üldjuhul näeb välja selline:

A b r a c a d a b r a

A brac ad abr

A brac ad ab

A brac ad a

A bracad

A braca

A brac

A b r a

$\mathrm{Abr}$

$\mathrm{A} \mathrm{b}$

A 
Nüüd esitame selle skemaatiliselt laulu "Il Pulcino Pio" struktuurina:

$$
\begin{aligned}
& \mathrm{A}^{2} \mathrm{a}^{6} \\
& \mathrm{~B}^{2} \mathrm{~b} \mathrm{a}^{5} \\
& \mathrm{C}^{2} \mathrm{c} \mathrm{b} \mathrm{a^{4 }} \\
& \mathrm{D}^{2} \mathrm{dcb} \mathrm{a}^{3} \\
& \mathrm{E}^{2} \mathrm{edcb} \mathrm{a}^{4} \\
& F^{2} f \text { e d c b a } a^{3} \\
& \mathrm{G}^{2} \mathrm{~g} \text { fe d c b a } \\
& \mathrm{H}^{2} \mathrm{~h} \mathrm{~g} \mathrm{fed} \mathrm{c} \mathrm{ba}{ }^{3} \\
& \mathrm{I}^{2} \mathrm{ihgfed} \mathrm{c} \mathrm{b} \mathrm{a} \\
& J^{2} \text { jihgfedcb a } \\
& \mathrm{K}^{2} \mathrm{kj} \mathrm{ihgfedcba^{3 }} \\
& \mathrm{L}^{2} \mathrm{l}^{3} \mathrm{a}
\end{aligned}
$$

(Tähed tähistavad siin loomi (suurtäht looma esmamainimist, väike täht selle järgmist mainimist akustilise vormeliga), numbrid märgivad vastava elemendi kordamiste arvu.)

Nagu näeme, on struktuur väga sarnane, kuid järjestus vastupidine: loitsu puhul on eesmärk tähtede (ja vastavalt ka nendega kodeeritava nähtuse) elimineerimine, käesolevas artiklis vaadeldaval juhul kasvab elementide hulk pidevalt, kuid katkeb lõpuks ootamatult. Nii ühel kui ka teisel juhul on oluline faktor loendamine, mis ei ole ilmselgelt eksplitseeritud, (s.t numbreid ei nimetata), kuid on teksti korrastamise aluseks, mis iseloomustab rituaalse iseloomuga tekste. Rõhutades arhailistes rituaalides diskreetsete järgijate taastootmise olulisust, et tagada Kosmose võit Kaose üle (maagiliste tekstide peaülesanne), omistas Vladimir Toporov määrava rolli arvujadadele: "Arvujada [---] on korra lihtsaim mudel, aga kord tagab stabiilsuse vastukaaluks kasvavatele entroopilise iseloomuga tendentsidele. Loendamine tähendab kaitsetute kogumist korra kaitse alla, ja loendatakse seda, mis kehastab elu ja tagab selle (vrd: жизнь: живот: животные [elu: kõht: loomad])" (Toporov 2005: 195). Selle tsitaadi viimast mõttekäiku võib otseselt seostada "Tibupoeg Pioga".

Loendamisega tekib omakorda rütm. Margarita Lekomtseva märgib, et "teksti fikseeritud pikkus moodustub karmi rütmilise skeemiga, mis on määratud lähtesõnaga" (Lekomtseva 1993: 219). Seda võib kohaldada ka analüüsitavale tekstile, kus lähtesõnaks on "tibupoeg Pio", aga ülejäänud koostiselemendid liituvad sellega, toetades struktuuri (vrd ka loitsudes esinevaid arvukaid rütmiliselt organiseeritud mitmesuguste objektide loetelusid). Loitsude puhul kirjutab Svetlana Tolstaja rütmi rollist: "Loitsudes on rütmiline organiseeritus mitte niivõrd esteetiline, kuivõrd pragmaatiline kokkuleppeline võte, see on igasuguse sugestiivse teksti hädavajalik instrument, mis tagab loitsu maagi- 
lise jõu" (Tolstaja 2005: 292). Rütmi mõjust teadvusele kirjutab Lekomtseva: "See rütm viib teadvuse seisundi muutuseni, milles algne semiootiline olukord muutub jagamatuks-liigendamatuks, kus kõik selle koostisosad sulavad üheks" (Lekomtseva 1993: 221).

Mis puudutab teadvuse muutunud seisundeid, siis on uurijad ammu märganud rütmiliste luuletekstide (need ei pea sugugi olema alati isegi muusikalised) mõju ajukoorele: "Aju töö [---] on oma olemuselt rütmiline. On juba hästi teada, et visuaalsete ja audiaalsete stiimulite kordamisega võib neid rütme tekitada või tugevdada kuni tavatute subjektiivsete seisundite saavutamiseni" (Turner \& Pöppel 1995: 77). Asi on selles, et rütmi (nagu muusikat üldse) võtab vastu aju parem poolkera, samal ajal keelt võtab vastu vasak, seetõttu aktiviseerib meetriline poeesia, eriti kui see on paigutatud muusikasse, samaaegselt mõlemat ajupoolkera, mis tingib "stereoskoopilise" maailmatunnetuse. Tundub, et see võib kehtida iga suvalise muusikalis-poeetilise teose kohta. Kuid erilise efekti tagab rütmi vastavus aju teatud sisemistele füsioloogilistele rütmidele, mis viib transiseisundisse. Selliste seisundite tüüpiline näide on šamaani riitus või rituaalsed tantsud. "Rituaalide raison d'être seisneb bioloogiliste ja sotsiaalsete rütmide kooskõlastamises, mõjustades kontrollitavates tingimustes neurofüsioloogilisi struktuure. Õigesti sooritatud rituaalid loovad heaolu- ja kergendustunde. Osalt on see seletatav asjaoluga, et nad lõdvestavad pikki ja intensiivseid stresse. Peale selle kasutatakse rituaalides erilisi sunnivõtteid, mis suurendavad närvisüsteemi tundlikkust ja "häälestavad" selle nii, et vähendada survet parempoolse ajupoolkera aktiivsusele ja teha võimalikuks selle ajutine domineerimine" (D’Aquili et al. 1979: 144; tsit Turner \& Pöppel 1995: 91). Just see efekt on täheldatav laulu "Tibupoeg Pio" järgi tantsitavate "rituaalsete tantsude" puhul. Kuid kas kõik on seletatav üksnes õigesti valitud rütmiga? Kui see nii oleks, poleks vaja mingit sisu, aga see on ometi olemas, ja nagu selgub, pälvib erilist tähelepanu.

\section{Kumulatiivsuse põhjused ja eesmärgid}

Seega sisu - see on raadios olevate ja iseloomulikult häälitsevate loomade loetelu. Internetikommentaatorid meenutavad kohe selle laulukese analooge, mis on seotud samuti loomadega. Kõige sagedamini tuuakse välja kaks: lastelaul "Nella vecchia fattoria" ("Vanas talus") ${ }^{6}$ ning folklaulja ja helilooja Angelo Branduardi "Alla Fiera dell'Est" ("Idamaisel turul") 7 . Esimene on USAs 1917. aastal avaldatud inglise lastelaulu "Old MacDonald had a farm" (eesti keeles "Taadil tare künka peal”) itaaliakeelne tõlge, laul on tõlgitud 13 keelde. Tekst koosneb talus elavate loomade korduvast loetlemisest koos neid iseloomustavate häälitsustega. Laulu mudel on selline: 
Old MacDonald had a farm, EE-I-EE-I-O,

And on that farm he had a [animal name],

EE-I-EE-I-O,

With a [animal noise twice] here and $a$ [animal noise twice] there

Here a [animal noise], there

$a$ [animal noise], everywhere

$a$ [animal noise twice]

Old MacDonald had a farm, EE-I-EE-I-O.
Taadil tare künka peal, heia-heia-hoo, tal mitu [looma nimi] elas seal, heia-heia-hoo, kõlab [looma häälitsus kaks korda] siin, kõlab [looma häälitsus kaks korda] seal.

Täna [looma häälitsus], homme [looma häälitsus], iga päev üks [looma häälitsus kaks korda]. Taadil tare künka peal, heia-heia-hoo.

Kõige populaarsemates versioonides esinevad lehm, kana, lammas, siga ja part, pärast iga looma nimetamist meenutatakse kõiki eelmisi. Võiks öelda, et see laul on üles ehitatud täpselt sama printsiibi järgi nagu "Tibupoeg Pio", kuid "MacDonaldsi talu" laulus pole mingit loomade hierarhiat, puudub ka eredalt väljendatud finaal. Faktiliselt võiks selle laulu liigitada lõppematute laulude sekka, kuivõrd loomi võib vabal valikul lisada ja nende valik sõltub üksnes esitaja fantaasiast.

Palju konkreetsem on teise mainitud laulu ("Idamaisel turul") struktuur. See pärineb juudi laulust "Üks kitseke" (Chad gadya, aramea laps", ivriidis אחד גדי - Gedi ehad), mida lauldi paasaõhtu piduliku söömaja (seder) lõpul. See on kumulatiivse teksti ere näide (arvatakse, et see tekst oli kuulsa "Maja, mille Jack ehitas" (This is the house that Jack built) allikas), kus lükitakse tegelasi üksteise järele, ja iga uus tegelane hävitab eelmise: kõik algab laadalt ostetud kitsetallest, siis tuleb kass, kes sööb kitsetalle ära, seejärel murrab koer kassi, kepp lööb koera, tuleb tuli ja põletab kepi, vesi kustutab tule, härg tuleb joob vee ära, lihunik veristab härja, surmaingel viib ära lihuniku, pärast seda ilmub Jumal, kes kukutab surmaingli. Iga uue tegelaskuju mainimisel korratakse üle kogu rida. Selle laulu variandid on Euroopas nii levinud, et paljud teadlased on jõudnud ummikusse, püüdes välja selgitada selle allikat. Oletatakse, et juudi laul on tegelikult laenatud sakslastelt ja kujutab endast ballaadi "Der Bauer der schickt den Jokel aus" tõlget, ballaad omakorda pärineb prantsuse hällilauludest "Ah, tu sortiras, Biquette" ja "La petite fourmi, qui allait à Jérusalem". Tuleb öelda, et nende tekstide hämmastava sisulise sarnasuse juures (tegelaskujud on peaaegu samad) esineb neis oluline erinevus: saksa ballaadis ja prantsuse kitsest kõnelevas laulus keelduvad kõik tegelased sooritamast nõutavaid tegevusi (koer ei hammusta kitse (saksa laulus teeni- 
jat), kepp ei taha koera lüüa, tuli ei taha keppi põletada jne) ning alles pärast seda, kui ilmub otsustav tegelaskuju (sakslastel isa, prantslastel saatan), kes tahab tappa ahela viimast lüli, rulluvad kõik tegevused vastupidises korras (s.t lihunik tahab härga tappa, härg tahab vett juua, vesi tahab tuld kustutada, tuli tahab süüdata keppi jne kuni viimase tegelaseni, kes samuti väljendab soovi sooritada nõutav tegevus). Nii tekib suletud tsükkel, mis kordab otsest ja pöördelist protsessi, sealjuures mingeid tegevusi ei sooritata, vaid väljendatakse ainult kavatsust (või selle puudumist) midagi teha. See on vastuolus juudi laulu olemusega, kus iga tegelane saab palga juba sooritatud tegevuse eest, samal ajal kui siin on vastupidi: viimane tegelane paneb tegutsema kõik ülejäänud alates eelviimasest kuni esimeseni.

Ühe või teise teksti esmasuse üle võib vaielda, aga kui rääkida sisu sümboolsusest, leiab see just juudi traditsioonis väljakujunenud interpretatsiooni: vastavalt tänapäevastele juudi kommentaatoritele räägib "Chad Gadya" erinevatest rahvastest, kes Iisraeli maad vallutasid: kitseke sümboliseerib juudi rahvast, Jumal (isa) ostis valitud rahva välja kahe mündi eest (Movše ja Aaron), kass sümboliseerib Assüüriat, koer Babülooniat, kepp Pärsiat, tuli Makedoonia Aleksandrit, vesi Rooma impeeriumi, härg saratseene, tapamaja ristikandjaid, surmaingel türklasi. Kuivõrd tõlgendus on välja töötatud ajal, mil Palestiinas kehtis Türgi ülemvalitsus, on viimases stroofis eeldatavasti juttu juudi rahva tulevasest vabastamisest. ${ }^{8}$ See sümbolism on inglise antropoloogi Edward Burnett Tylori arvates argument selle poolt, et just see tekst säilitas oma algse vormi, aga selle ülejäänud analoogid on moonutatud töötlus (Tylor 1989: 76). Üks argument juudi teksti autentsuse poolt võib olla ka kitsetalle kujund: nagu teada, on kitsetall sageli Iisraeli rahva kehastus, kuid selle laulu teistes variantides on kitsetalle välja vahetanud hiir (prantsuse laul sipelgast, itaalia laul idamaisest turust) või on kitsetall üldse elimineeritud (nagu saksa variandis). Need asendused on mõistetavad: raske on ette kujutada, et kass võiks ära süüa kitsetalle (seda võib õigustada ainult allegooriaga), hiire puhul on see loogiliselt rohkem põhjendatud. Üldistavalt võib nende "Tibupoeg Pioga" seotud kahe tekstitüübi kohta öelda, et esimene tüüp ("MacDonaldi farm") sarnaneb sellele rohkem sisu poolest (loomade loetlemine neid iseloomustavate häälitsustega), teine ("Chad Gadya") on lähedasem struktuuri ja lõpetatuse poolest (kindlalt väljendatud elementide hierarhia ja ere finaal). Kuid "Tibupoeg Pio" ei korda täielikult neist kumbagi.

Võib-olla on kusagil isegi olemas selle täielik analoog, sest kumulatiivsed laulud on kõigi rahvaste pärimuskultuuris väga levinud tüüp (mis lubab rääkida selle arhailisusest ja universaalsusest). Vt vene traditsioonis tekst, mis osaliselt kordab itaallaste "Pulchinot": see on laul "Naisuke, muretseme õige maja" (Давай-ка, женушка, домик наживать), mis on üles kirjutatud Krasnojarski 
kraist. Selle süžee on järgmine: mees arendab oma naise ees ideed, kuidas koguda jõukust, ostes palju koduloomi: kanake, pardike, lambake, lehmake jne, andes loomadele ilmeka kujundliku iseloomustuse. Selliste ostude arv suureneb kumulatiivse kuhjumise reeglite kohaselt ja laulu lõpus kujutatakse sellist pilti:

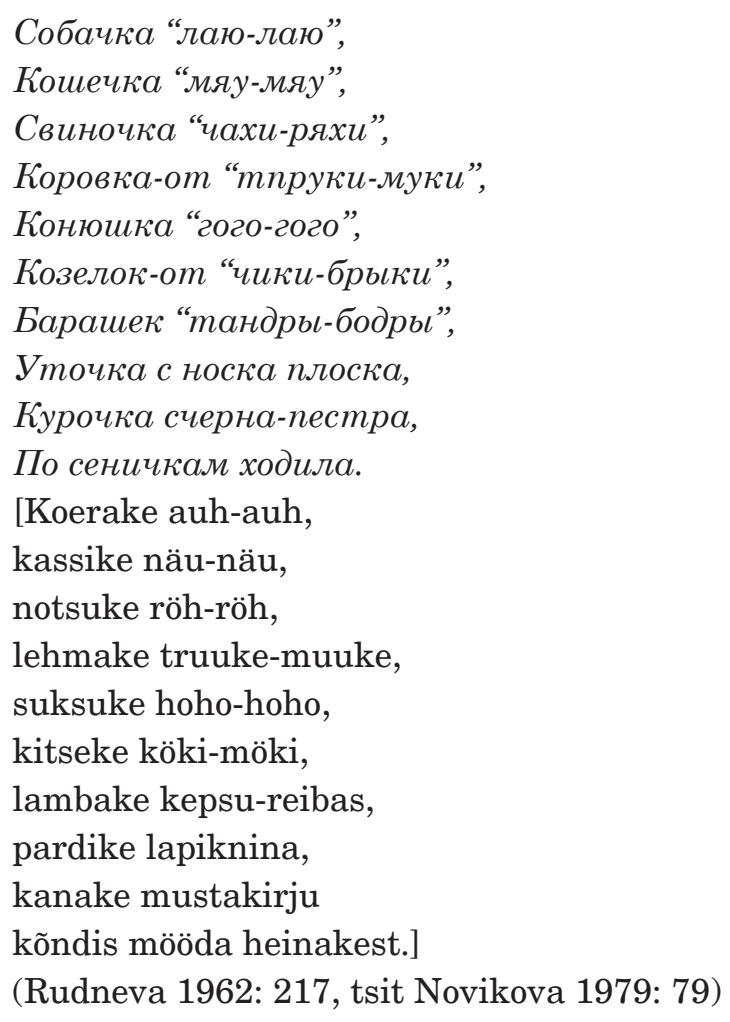

Tuleb öelda, et häälitsust jäljendavatel hüüdnimedel on selles kontekstis oluline roll: "nende abil saadakse üle üksluisusest, süžee monotoonsusest. Iga tegelaskuju ilmub välja ainult talle omase eristava tunnusega. Uue tegelase selline ilmumine tekitab liikumise tunde" (Loiter 1979: 24).

Sellele vaatamata on tegevus (liikumine) olemas kõigis eelmainitud tekstides, samuti (kas või minimaalne) algus: vene laulus teeb mees naisele ettepaneku osta loomi; prantsuse hällilaulus läheb sipelgas Jeruusalemma, aga kits istub kapsa sees, kõik ülejäänud tegelased sooritavad samuti mingeid tegevusi. Sama võib öelda ka teiste kumulatiivsete laulude kohta, mida esineb erinevates pärimustes tohutul hulgal. Ent "Tibupoeg Pios" näeme teistsugust pilti: siin puudub selgesti väljendatud tegevus, kuid predikatiivset rolli täidavad helijäljendavad elemendid, mis kõige eredamalt ilmneb finaalis "Traktor põrr-rr, ja tibukene... oi-oi" - see tähendab, et traktori hääl tähistab hääleallika tegevust (liikumist), aga tibupoja hüüatus surma. Tuleb märkida, et samalaadne konstruktsioon ("telegraafistiil") on kõneomandamise varase staadiumi tunnus ja kõnevõime 
kadumise üks etappe ajukahjustuse korral (üksikasjalikumalt vt Lurija 1998; Spivak 2000). See on vastavuses teooriaga algsest sõna kaemuslik-praktilisusest (sympractical) ontogeneesi ja fülogeneesi vältel, mil sõnad tähistasid mitte eset või tegevust, aga situatsiooni tervikuna, s.t tegevused ja objektid sisaldusid ühes keelelises märgis, vrd: "Kui laps mängib hobusega ja ütleb "ptruu”, võib "ptruu" tähendada hobust ja rege ja istumiskäsku ja sõiduettepanekut ja peatumissoovi, sõltuvalt sellest, millises olukorras ja millise intonatsiooniga seda öeldakse ning millised žestid seda saadavad. Seetõttu, kuigi lapse esimene sõna on suunatud objektile, jääb see lahutamatuks tegevusest, s.t on kaemuslik-praktilise iseloomuga" (Lurija 1998: 37). See võimaldab pidada seda laadi tekste tõeliselt arhailisteks, teadvuse kõige iidsematele kihtidele ja mõtlemise kõige varasematele vormidele tuginevateks.

Tuleb öelda, et selliste tekstide relikte leidub mitte üksnes kumulatiivset tüüpi lauludes, vaid ka (isegi veel autentsemalt) kumulatiivsetes muinasjuttudes, mis tõenäoliselt pärinevad samast allikast nagu vastavad laulud, kuivõrd on samuti tihedalt seotud rütmiga: iseenesest "kumulatiivne printsiip on rütmi printsiip, katkematu rütm, kusjuures kõik helitekitajad on võrdsed. Sellele on allutatud jutu kõik tasemed. Rütmistuse poolest eristub jutu kogu sõnaline aines, mis sageli omandab luulelise või sellele lähedase vormi” (Loiter 1979: 27).

Sedalaadi tekstide kõige eredamad näited on vene muinasjuttudele "Naeris", "Kakuke", "Tare-tareke" jt sarnanevad lood. Tegelaskujude alanemine analoogiliste tegevuste või olukordade kordamise saatel loob pinge ja köidab tähelepanu lõpptulemuse ootel. Kusjuures tulemus on tavaliselt traagiline: kakuke söödi ära, tareke litsuti laiaks (meenutagem ka tibupoeg Pio lõppu). Faktiliselt kirjeldavad need muinasjutud lakooniliselt maailma loomise (sündimise) ja lagunemise (surma) akti. Vladimir Propp kirjutab nende kohta: "Nende muinasjuttude peamine kunstiline võte seisneb mingi tegevuse või elementide kordamises, kuni sellisel moel loodud ahel katkeb või laguneb laiali vastupidises järjekorras. [---] Kumulatiivsed muinasjutud on üles ehitatud mitte üksnes ahela põhimõttel, vaid ka kõige erinevamate kuhjumise või kasvamise ühendusvormidena, mis lõpeb mingi lõbusa katastroofiga. [---] Kuhjumisvormide mitmekesisuses peitubki nende muinasjuttude võlu ja sisu. Nad ei sisalda mingeid huvitavaid ega sisukaid süžeelisi "sündmusi”. Vastupidi, sündmused on kõige tühisemad (või saavad alguse tühistest) ja nende sündmuste tühisus on mõnikord koomilises kontrastis neist tulenevate tagajärgede ja lõpliku katastroofiga" (Propp 1976: 243). Tuletades meelde riimi ja rütmi tähtsust nendes muinasjuttudes, rõhutab Propp: "Iga uue lüli lisandumisel korduvad kõik eelmised. [---] Selles kordumises peitub nende muinasjuttude peamine võlu. Nende kogu mõte peitub värvikas kunstilises esituses. Nii iseloomustatakse käesoleval juhul iga looma mingi tabava sõna või mõne sõnaga, tavaliselt riimis (täi ronija, kirp kargaja, hiireke-kiireke, [---] konnake krooksuja, [---]). 
Nende täitmine nõuab suurt meisterlikkust. Olenevalt esitusest lähenevad nad mõnikord kiirkõnele, mõnikord neid lauldakse. Nende kogu huvitavus on huvi koloriitse sõna kui sellise vastu. Sõnade kuhjumine on huvitav siis, kui sõnad on ka iseenesest huvitavad. Sellepärast püüdlevad sellised muinasjutud rütmi, luule, konsonantsi ja assonantsi poole" (Propp 1976: 247). Seejuures tema arvates "kumulatsiooniprintsiipi tajume me kui relikti, kui mingite varajaste teadvusvormide produkti" (Propp 1976: 248). Samast asjast kirjutab ka Vladimir Toporov, seostades "Tare-tarekese" tüüpi loomade osalusega muinasjutte paleoliitikumi maalingutega (täpsemalt maa-aluste pühakodade seinajoonistustega), mis põhineb samasugusel loomade "liitmisel" olemasoleva kogumiga (Toporov 2010: 57).

Sel moel suunavad mitte üksnes (tinglikult) "nominatiivsed" tekstid, vaid ka üksteise kõrvale lükkimine meid kõige varasemate, primitiivsemate (nii ontoloogiliselt kui ka fülogeneetiliselt) mõtlemisvormide juurde. Aheljutustusi nimetatakse sageli reliktseteks, neid leidub kõigil maailma rahvastel ja need on suunatud kõige noorematele kuulajatele, kes alles hakkavad omandama kõnet ja tunnetama maailma. Staatilise lükkimise võtet (s.t tegelaskujude mistahes tegevuse puudumine, üksnes nende nimed) loetakse ootuspäraselt seda tüüpi tekstide veelgi iidsemaks alaliigiks. Võrrelgem "Tibupoeg Pio" klipis esinevat rida sellega, mida ütleb staatilise muinasjutu kohta Irina Amrojan: "Selles ei ole faktiliselt mingit liikumist, ta meenutab pildivalikut, slaide: tegelased ilmuvad järgemööda lavale ja jäävad sinna etenduse lõpuni. Kuskohast nad tulid, mis tõi neid just sellesse kohta, muinasjuttu ei huvita. Peale selle ei soorita muinasjututegelased mingeid tegevusi - [---] nad lihtsalt nimetavad ennast" (Amrojan 2005: 135). Autor seostab selliseid muinasjutte lapse kõne arenguga: ontogeneesis ilmuvad leksika arengu käigus (kui sõna läheb kaemuslik-praktilisest (sympractical) staadiumist juba üle sünsemantilisse süsteemi) objektid (ja neid tähistavad nimisõnad) kõnesse varem kui tegevused ja neid tähistavad tegusõnad. Vastavalt sellele on staatilised kumulatiivsed muinasjutud määratud eelkõige maailma nimetama, sellega tutvustama: "Kogu see sõnaline tegevus meenutab iseäranis lapse tegevust kõige varasemas eas, mil ta ei ole veel tuttav sõnaga, püramiidimängu. Muinasjutt "Tare-tareke" on meie seisukohalt samasugune klotside virnastamine, kuid kuubikute asemel on sõnad: nimisõnad, nimetused. Ja samuti nagu laps õppis kompides tundma esemeid enda ümber, õpib ta tundma sõnakujundite maailma. Just seetõttu põhineb selliste muinasjuttude struktuur võtetel, mille funktsioon on tutvustada, huvi äratada (eritlev lükkimine), muljet avaldada, aidata meelde jätta, see tähendab anda aega meeldejätmiseks (kumulatsioonivõte)" (Amrojan 2005: 136). Siin võib lisada, et loomad on maailma ühed esimesed elemendid, millega laps tutvub, aga paremaks meeldejätmiseks on tekstides neid loomi lastele esitatud (või isegi nimetatud) nende häälitsuste abil. Hierarhia tekkimisel (nagu 
“Tibupoeg Pio" puhul) on tegu ka kategoriseerimise õpetamisega - maailma tunnetamise järgmine etapp.

Sel moel loob lükkimise või kumulatsioonivõte (hierarhia loomine) kinnitava efekti ja paelub kuulaja (“Tibupoeg Pio" puhul vaataja) tähelepanu. Siinkohal tuleb märkida (arvestades “Tare-tarekese” ja "Tibupoeg Pio" süžee lähedust), et tarekese rolli täidab teisel juhul raadio kui mingi virtuaalne reaalsete tegelastega täidetud ruum, mis annab sisule veelgi kontrastsema efekti.

\section{Videoklipi anatoomia}

Tulles tagasi uurimisobjekti juurde, tuleb rõhutada, et selle klipi puhul suurendab tähelepanu paelumise efekti mitmekordselt videorida: loomi mitte üksnes ei nimetata, vaid ka näidatakse eredate piltidena, kusjuures need on rõhutatult primitiivsed (nagu lasteraamatutes), ilma liigsete detailideta ja lihtsal erinevate värvide taustal (igale loomale vastab kindel värv, mis samuti aitab kaasa meeldejätmise efektile):
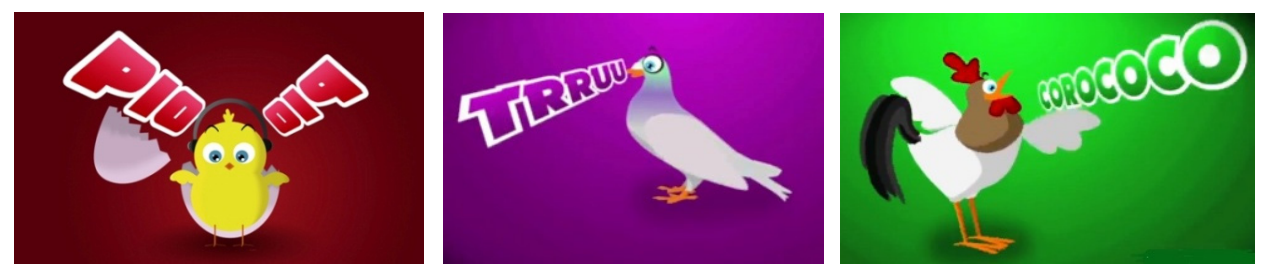

Selline efekt puudub teistel samalaadsete laulude klippidel: brasiilia analoogil, aga ka tsiteeritud "kumulatiivsetel laulukestel" vanast farmist ja idamaisest turust. Märkimisväärne on ka see, et tegelasi on selles klipis 12 - tõenäoliselt ülemäärase väsitamiseta tähelepanu köitmiseks maksimaalne arv (võrdluseks: brasiilia laulukeses tibupojast on neid 13, laulus kitsekesest 10, farmilaulus 5).

Ka helil on klipis üsna oluline roll: meloodia ja rütmi kõrval on see stiliseeritud laste järgi ja tundmatuseni on muudetud tuntud lauljanna Morgana Giovannetti häält. Nagu täheldas üks kommentaator: "Tibupoeg Piol on edu, sest see "räägib lugu", mida kõik teavad tänu Branduardile, lugu järjekindla motiivi, haarava rütmi, ereda graafika ja teatud staadiumini kileda häälega. Lapsed, kellele seda näidatakse esimest korda, hakkavad naerma ammu enne seda, kui näevad finaali traktoriga. Olen kindel, et selle teose edu aluseks on heli" (Pallera 2012). 
Niimoodi omandab "tuntud lugu" värvi ja heli, muutub tunnetatavaks ja tekitab soovi mängida seda veel ja veel (vt arvukad instseneeringud ja tantsud vastavate loomade imiteerimisega, mida kommentaatorid nimetavad "suguharutantsudeks"). On huvitav, et “Tibupoeg Piosse" suhtumine sarnaneb suhtumisega reaalsesse olendisse: tema vihkajad ihkavad internetis temaga "kohtuda", teda "tappa", "tükeldada”, “ära süüa”. Vrd kõige õnnestunuma paroodia teksti ("Vihkan tibupoeg Piot”, Michael Righini): “... ma tahaksin, et ta sureks, / tahaksin, et ta lõhkeks, / tahaksin, et ta kannataks / tahaksin, et ta kaoks, / et piinleks... / Ma tahaksin kohtuda tibupoeg Pioga / tahaksin, et mul oleks tibupoeg Pio, / et teda tappa, / et teda põrmustada, / et teda puruks litsuda, / teda piinata, / lõpuks lahata / ja pärast ära süüa..." Klipis kisendab tänaval kuuldud laulust hullunud noormees juhuslikule vastutulijale (muide, mingil moel meenutab too tibupoega): “Aitab!", pärast seda esitab muusika saatel emotsionaalse monoloogi oma vihast tibupoja vastu ja lõpuks tulistab oma teisikut, kes seda taas kuulab (http://www.youtube.com/watch?v=P7bpqyT-128). ${ }^{9}$ Tuleb märkida, et selle paroodia rütmiline struktuur kordab täielikult originaallaulukese rütmi: $2+4(+2)=6(8)$ ühe ja sama segmendi kordust. Ka finaal on täpselt sama - peategelase surm.

Rääkides surmast, tuleb käesoleval juhul meenutada, et kõik “Tibupoeg Pio" efekti üle mõtisklenud uurijad märgivad seda laulukese eduloo määrava momendina. Tõepoolest, autorite loodud originaalklipi duubel muudetud lõpuga (kogu klipi vältel ennast treeninud tibupoeg annab lõpus traktorile poksikindaga hävitava löögi) ei tekita vaatajates sellist huvi ja pigem ei meeldi neile.

Sotsioloog Mirko Pallera, kes püüdis vaadelda kirjeldatud fenomeni TEC (Tensione, Emozione, Catarsi - pinge, emotsioon, katarsis) mudeli abil, näeb klipi lõpus omamoodi katarsist, mida vaataja peab kogema: "Mulle tundub, et "Tibupoeg Pio" poolt esile kutsutud katarsis seisneb koomilises lõpus, nimelt hetkes, mil traktor lömastab enamiku vaatajate suureks sadistlikuks rõõmuks luuletuse lõputu kordamise tõttu juba vihatuks muutunud pisikese tibupoja. [---] Emotsioon on rõõm: korduvad riimid rahumeelsete loomade ja nende häältega muudavad meid lasteks ja äratavad meis süütuse arhetüübi, mille tasuks on elu puer aeternus [igavene noorus] puutumatus paradiisis, mis on asustatud kõigi nende laulvate ja tantsivate loomadega, kuid see elu on pidevas ohus - kerge on muutuda naiivseks ja sel kombel tüütult vihatavaks ning sellepärast tuleb sind tuua reaalsusse täiskasvanuliku ja mõnevõrra julma (et mitte öelda sadistliku) žestiga. See on omamoodi vabatahtlik ja sihilik "paradiisi langemine", kaob ideaalne koht, kus tahame hoida oma lapsukesi, kuid mis võib transformeeruda võltsiks ja ebareaalseks paigaks, kutsudes esile vastandtundeid: küünilisus, sadism, nihilism. Ja just see kontrast annab sellele filmile kultusliku fenomeni!" (Pallera 2012). 
Sellele analüüsile võib lisada, et arhetüüpidest rääkides ei tohi unustada sümbolistlikku kujundit kandvat peakangelast - tibupoega, kes süütuse kõrval kehastab elu algust. Tuletame meelde, et klipi alguses vupsab ta välja munast - universaalne sündimise ja maailmaloomise sümbol. See kujund sünnitab teadvuses kõige tähtsamate ja esmaste eksistentsiaalsete üleelamistega seotud assotsiatsioone, seepärast on loogiline, et kui klipp algab sünniga, peab ta lõppema surmaga. Peale selle esineb mõnede Aafrika ja Lõuna-Ameerika rahvaste rituaalides tibupoja ohverdamist, tibu arvatakse olevat seotud surnute hingedega, hingede saatja initsiatsiooniriitustes ja teiste religioonilis-maagiliste pühade puhul (Herder 1986: 37). Tõenäoliselt leidsid need arhailised ettekujutused kajastuse ka tänapäeva folklooris: tuletagem meelde laulukest praetud ja aurutatud tibupojast (“Цыпленок жареный, иыпленок пареный”), kes tahab elada, kuid lõpuks siiski sureb (vt selle teksti analüüsi Nekljudov 2005).

\section{Kokkuvõtteks}

Ülaltoodut kokku võttes tuleme tagasi selle analüüsi põhiküsimuse juurde: mis on see, mis köidab ja lummab selle "lömastatud tibupojast rääkiva igava ja tüütu loo" puhul. Toome välja peamised (juba mainitud) tegurid, mis määravad "nakatavuse":

1) lastelaulu vorm, mis meenutab samaaegselt kumulatiivseid muinasjutte, liisusalme, loitse, primitiivseid laulukesi jne, mis viitavad rituaalsete tekstide religioonilis-maagilise tähendusega jäänukvormidele;

2) teksti ja videojada ahelstruktuur, mis tekitab assotsiatsioone laste kuubikute, sõnastikupiltide ja esimeste mängudega (matrjoškad, püramiidid) ning viib vaataja tagasi muretusse lapsepõlve. Vähem oluline pole ka ahela lülide optimaalne arv (12), millest rohkem oleks väsitav, aga vähem ebapiisav;

3) helirida, mis koosneb korraga loomade häälejäljendustest ja kergest meeldejäävast (nähtavasti aju vastuvõtu seisukohalt “õigest”) rütmist, mis koos eelloetletud faktoritega viitab taas rituaalsetele tantsudele ja suguharude põlistele kommetele, milles korduval rütmil oli esmajärguline tähtsus. Siin tuleb märkida ka muusika taktis pead liigutavate loomade rütmilist liikumist - see loob lummava mulje nagu pendli liikumine, mida kasutatakse hüpnotiseerimisel;

4) ootamatu (ja samal ajal alateadlikult oodatud) finaal, mis loob omalaadse hierarhilise järgnevuse katkemise efekti (üldisesse loomade ritta mittekuuluv traktor) ja samal ajal viitab arhetüüpsetele ettekujutustele rituaalsest ohverdamisest. See ilmselge ja varjamatu kontrast, mis realiseerub idüllilise pildi vahetumisega sadistlikuga, sisaldab endas 
tõenäoliselt üht olulist, kui mitte peamist põhjust, miks see klipp on nii paeluv;

5) lõpuks arhetüüpsete ettekujutuste kompleks, mis on seotud tibupoja ja muna sümboolikaga ning puudutab teadvuse kõige eksistentsiaalsemaid kihte.

Tundub, et suguharu rituaalsete tantsude ekstaasiga võrreldava tugeva efekti põhjustab just kõigi nende tegurite koostoime, mitte ükski neist eraldiseisvana. Sellest kõneleb ka psühhiaater Antonio Picano (Rooma San Camillo Forlanini haigla psühhiaatriaosakonna juhataja): "Need videod avaldavad mõju impulsiivsele mehhanismile, mille aju käivitab, et talitseda ärevust. [---] Impulsiivseid mehhanisme iseloomustab tendents saavutada kontroll mõistuse üle, täita tühjust, hõivata "mentaalne ruum". See on sama hea kui usaldada osa iseendast korduva motiivi hoolde" (Capocelli 2012). Umbes sama, kuid palju lihtsamate sõnadega ütles välja üks internetikommentaator: “... kui hakkad lõputult kordama seda või suvalist teist sõnajada, isegi mõttetut, muutub see tõeliseks mantraks. Selle funktsioon on peatada jutukas mõte teadvuses. See on see, mida meil kõigil on vaja, et teadvust tühjendada ja vabastada ärevusest" (Pallera 2012).

Niisiis saab selgeks “Tibupoeg Pio" mehhanism ja eesmärk: saada eksalteeritud nauding, vabastada mõistus ärevusest, sukeldudes lapsikusse, primitiivsesse, ürgsesse seisundisse, mille kutsuvad esile üheaegselt kasutatavad visuaalsed, audiaalsed ja semantilised võtted, mis on suunatud kollektiivse alateadvuse arhetüüpide aktiviseerimisele.

\section{Tõlkinud Asta Niinemets}

\section{Kommentaarid}

1 Aitäh T. V. Tsivjanile temalt artikli ettevalmistamise käigus saadud väärtuslike märkuste ja kommentaaride eest.

2 Tekstitöötlus: Maurizio Paniconi, Morgana Giovannetti, Lucio Scarpa; muusikaline töötlus: Lucio Scarpa ja Davide Pistoni; esitus Morgana Giovannetti.

$3 \mathrm{Vt} \mathrm{nt} \mathrm{http://www.youtube.com/watch?v=3jJfv5s-gWU.}$

4 http://www.youtube.com/watch?v=z9V0z_BFHRI (vaadatud 12. detsember 2013 - ei ole enam kättesaadav).

5 E o pintinho piu: http://www.youtube.com/watch?v=0aJYrCoN7bc.

${ }^{6} \mathrm{http}: / /$ www.youtube.com/watch?v=Lr4EStuduKo.

$7 \mathrm{http} / / / \mathrm{www}$. youtube.com/watch?v=IaeRmVy9fwI\&feature=related.

8 http://ru.wikisource.org/wiki/\%D0\%95\%D0\%AD\%D0\%91\%D0\%95/\%D0\%A5\%D0\% B0\%D0\%B4-\%D0\%93\%D0\%B0\%D0\%B4\%D1\%8C\%D1\%8F. Tänan Keren Dubnovi (Jeruusalemm) selle teksti selgitamise ja kommenteerimise eest.

9 See video ei ole enam kättesaadav. 
“Tibupoeg Pio” maagia ehk väärtusliku traditsioonilise teksti ootamatust esiletõusust

\section{Kirjandus:}

Amrojan, Irina 2005. Povtor v strukture fol'klornogo teksta. Na materiale russkikh, bolgarskikh i cheshskikh skazochnykh i zagovornykh tekstov. Moskva: Gos. respublikanskii tsentr russkogo fol'klora.

Caliandro, Alessandro \& Beraldo, Davide 2012. Il caso Pulcino Pio: DNA virale e potere ontologico del brand. Centro Studi Etnografia Digitale 7. september (http:// www.etnografiadigitale.it/2012/09/il-caso-pulcino-pio-dna-virale-e-potere-ontologicodel-brand/ - 6. november 2014).

Capocelli, Roberto 2012. L'esperto, il contestato "Pulcino Pio" attua un meccanismo compulsivo che contiene l'ansia. Avanti! 4. september (http://www.avantionline. it/2012/09/secondo-lesperto-il-contestato-pulcino-pio-attua-un-meccanismo-compulsivoche-contiene-lansia/\#.UJ2K1eQgbW8 - 6. november 2014).

D'Aquili et al. 1979 = D'Aquili, Eugene \& Laughlin, Charles D. \& McManus, John (toim). The spectrum of ritual: A biogenetic structural analysis. New York: Columbia University Press.

Herder 1986 = Herder Lexicon. The Herder symbol dictionary. Symbols from Art, Archaeology, Mythology, Literature, and Religion. Wilmette, Illinois: Chiron Pubns.

Lekomtseva, Margarita 1993. Semioticheskii analiz odnoi innovatsii v latyshskikh zagovorakh. Nikolaeva, T. M. (vast toim). Issledovaniia v oblasti balto-slavianskii dukhounoi kul'tury. Zagovor. Moskva: Nauka, lk 212-226.

Loiter, Sofia 1979. O zhanrovoi spetsifike kumuliativnoi skazki. Problemy izucheniia ustnogo narodnogo tvorchestva. Respublikanskii sbornik 6. Moskva: Izd-vo MOPI im. N. K. Krupskoi, lk 18-28.

Lurija, Aleksandr 1998. Iazyk i soznanie. Rostov-na-Donu: Feniks.

Melnikova, Larissa 1990. Priemy postroeniia tekstov schitalok. Matvejeva, Rufina (toim). Russkii fol'klor Sibiri. Elementy arkhitektoniki: sbornik nauchnykh trudov. Novosibirsk: Nauka, lk 112-126.

Metškovskaja, Niina 1998. Iazyk $i$ religiia. Lektsii po filologii i istorii religii (gl. 40: Schitalki i drugie fol'klornye potomki zagovorov). Moskva: Izdatel'sko-torgovyi dom GRAND (http://www.litmir.net/br/?b=19433 - 4. november 2014).

Nekljudov, Sergei 2005. “Tsyplenok zharenyi, tsyplenok parenyi...”. Toporov, Vladimir (vast toim). Iazyk. Lichnost'. Tekst. Sb. st. k 70-letiiu T. M. Nikolaevoi. Moskva: Iazyki slavianskikh kul'tur, lk 637-649.

Novikova, Anna 1979. Problemy izucheniia ustnogo narodnogo tvorchestva. Respublikanskii sbornik 6. Moskva: Izd-vo MOPI im. N. K. Krupskoi, lk 75-89.

Pallera, Mirko 2012. Perché il Pulcino Pio è virale. Ninja Marketing 10. september (http://www.ninjamarketing.it/2012/09/10/pulcino-pio-marketing-video-virale - 6. november 2014).

Propp, Vladimir 1976. Kumuliativnaia skazka. Fol'klor $i$ deistvitel'nost'. Izbrannye stat'i. Moskva: Nauka. 
Rudneva, Anna (koost) 1962. Russkie narodnye pesni Krasnoiarskogo kraia. Moskva: Sov. Kompozitor.

Spivak, Dmitri 2000. Izmenennye sostoianiia soznaniia: psikhologiia i lingvistika. SanktPeterburg: Iuventa.

Tylor, Edward Burnett 1989 = E. B. Tailor. Pervobytnaia kul'tura. Moskva: Izdatel'stva politicheskoi kul'tury.

Turner, Frederick \& Pöppel, Ernst 1995 = F. Terner \& E. Peppel'. Poeziia, mozg i vremia. Rentschler, Ingo \& Herzberger, Barbara \& Epstein, David (toim). Krasota $i$ mozg. Biologicheskie aspekty estetiki. Moskva: Mir (http://zeigarnik.ru/tmp/Beaty_and_the_ brain.pdf - 4. november 2014).

Tolstaja, Svetlana 2005. Ritm i inertsiia v strukture zagovornogo teksta. Svešnikova, T. N. (vast toim). Zagovornyi tekst. Genezis i struktura. Moskva: Indrik, lk 292-308.

Toporov, Vladimir 2005. Chislovoi kod v zagovorakh. Po materialam sbornika L. N. Maikova "Velikorusskie zaklinaniia". Svešnikova, T. N. (vast toim). Zagovornyi tekst: genezis i struktura: Moskva: Indrik, lk 194-246.

Toporov, Vladimir 2010. K proiskhozhdeniiu nekotorykh poeticheskikh simvolov. Paleoliticheskaia epokha. Toporov, Vladimir. Mirovoe derevo. Universal'nye znakovye kompleksy 1. Moskva: Rukopisnye pamiatniki Drevnei Rusi.

\section{Summary}

\section{Magic of the Little Chick Cheep: A Sudden Emergence of a Valuable Traditional Text}

\section{Maria Zavjalova}

Keywords: counting-out rhymes, folklore, hits, mass culture, The Little Chick Cheep

The article focuses on the song "Il Pulcino Pio" (in Eng. The Little Chick Cheep), which was released and became a real hit in Italy in 2012, analysing the reasons for its popularity. In a more detailed investigation of the ostensibly simplistic song with no special content, the author explains its deep semiotic meaning and derivation from the most ancient layers of consciousness. The analysis points to the main factors that helped the song get fixed in the minds of the general public: children's song form reminding of cumulative fairytales, counting-out rhymes and primitive ditties; the chain structure of the alternating text and video; imitations of animal sounds and easily memorable rhythm, and an unexpected finale.

The analysis elucidates the mechanism and purpose of "The Little Chick Cheep": to derive exalted pleasure, free the mind from anxiety, by delving into a childish, primitive, primal state, which is generated by simultaneous visual, audial and semantic techniques directed at activating the archetypes of collective subconsciousness. 